\title{
Pork: profile of the West of Paraná consumers and physical evaluation of chop
}

\section{Carne suína: perfil de consumidores do Oeste do Paraná e avaliação física de bisteca}

\author{
Rosana Aparecida da Silva-Buzanello ${ }^{1 *}$; Daneysa Lahis Kalschne ${ }^{1}$; \\ Silmara Maisa Heinen²; Claudete Pertum²; Alexia Francielli Schuch; \\ Marinês Paula Corso ${ }^{4}$; Cristiane Canan ${ }^{5}$
}

\begin{abstract}
Pork consumption in Brazil is still low despite its productive importance. Relevant issues such as swine breeding, meat quality, and evaluation of aspects and attributes considered important by pork consumers at the time of purchase allows identifying consumer market demands. Moreover, physical parameters evaluation or pork cuts are suggested to certify the meat quality. The aim of this study was to identify the current situation of pig farming and determine the main aspects considered by consumers when buying pork in the Western region of Paraná state, Brazil. Furthermore, the physical properties of five pork chop brands marketed in the region were determined. Initially, an exploratory research was conducted involving ten pig farming sector professionals. This research allowed identifying that professionals understand the factors affecting meat quality and that some municipalities in the region are beyond their absorption capacity for pig production market. A descriptive research involving one hundred pork consumers showed that, although most prefer beef, $41 \%$ reported to consume pork 2 to 3 times a week. Pork chops and ribs are the preferred cuts, either fried or roasted. Details such as expiration date and federal inspection register were considered the most important aspects at the time of purchase, while price was the least important one. The meat color was the most mentioned sensory attribute. The physical analyses of five pork chop brands showed no $\mathrm{pH}$ difference $(\mathrm{p}>0.05)$, water holding capacity, and cooking loss results, distinctive from the one observed for color $\left(\mathrm{L}^{*}, \mathrm{a}^{*}\right.$ and $\left.\mathrm{b}^{*}\right)$ and shearing force, which showed differences among the brands $(\mathrm{p} \leq 0.05)$. Comparing $\mathrm{pH}$ and $\mathrm{L}^{*}$, it can be suggested that two brands showed normal meat characteristics, one DFD meat $\left(\mathrm{pH}>6.0\right.$ and $\mathrm{L}^{*}<$ 45 ), and other two brands PSE ( $\mathrm{pH}<5.8$ and $\mathrm{L}^{*}>50$ ). The research contributed to identifying features considered important by pork consumers, suggesting strategic actions to achieve greater preference and consumption index. The evaluation of physical parameters showed there is variability involved in pork chop quality as the samples were obtained from commercially different origins and under different processing and storage conditions.
\end{abstract}

Key words: Quality attributes. DFD meat. PSE meat. Purchase behaviour. Shearing force. Descriptive research.

\footnotetext{
${ }^{1}$ Pesquisadoras, Doutorado em Ciência de Alimentos, Universidade Estadual de Londrina, UEL, Londrina, PR, Brasil. E-mail: rosanabuzanello@gmail.com; daneysa@hotmail.com

2 Discentes, Graduação em Tecnologia em Alimentos, Universidade Tecnológica Federal do Paraná, UTFPR, Medianeira, PR, Brasil.E-mail: silmaraheinen@hotmail.com; claudete_pertum@hotmail.com

3 Pesquisadora, Mestrado em Tecnologia de Alimentos, UTFPR, Medianeira, PR, Brasil. E-mail: alexiafschuch@gmail.com

${ }^{4}$ Prof ${ }^{a}$, Departamento Acadêmico de Alimentos, UTFPR, Medianeira, PR, Brasil. E-mail: corso@utfpr.edu.br

${ }^{5}$ Prof $^{\text {a }}$, Mestrado em Tecnologia de Alimentos, UTFPR, Medianeira, PR, Brasil. E-mail: canan@utfpr.edu.br

* Author for correspondence
} 


\section{Resumo}

O consumo de carne suína no Brasil ainda é baixo, apesar da importância produtiva. Questões relevantes a suinocultura, qualidade da carne e avaliação de aspectos e atributos considerados importantes por consumidores no momento da compra possibilitam identificar a demanda do mercado consumidor. Além disso, a avaliação dos parâmetros físicos de cortes é sugerida para atestar a qualidade. Este trabalho teve como objetivo identificar a situação atual da suinocultura e determinar os principais aspectos e atributos considerados pelos consumidores no momento da compra de carne suína na região Oeste do Paraná. De forma adicional, os parâmetros físicos de cinco marcas de bistecas suínas comercializadas na região foram determinados. Inicialmente, uma pesquisa exploratória foi realizada com dez profissionais do setor suinícola, que demonstraram conhecer os fatores que interferem na qualidade da carne obtida e que algumas cidades da região estão ultrapassando a capacidade de absorção do mercado de produção de suínos. Uma pesquisa descritiva com cem consumidores mostrou que apesar de a maioria preferir carne bovina, $41 \%$ declararam consumir carne suína de 2 a 3 vezes por semana. Os cortes preferidos foram bisteca e costela, consumidos na maioria das vezes fritos ou assados. Itens como validade e registro de inspeção federal foram considerados os de maior importância no ato da compra enquanto o preço foi o menos importante. Quanto aos atributos sensoriais, a cor da carne foi a mais citada. $\mathrm{Na}$ avaliação física de bistecas de cinco marcas comerciais não houve diferença $(p>0,05)$ nos resultados de $\mathrm{pH}$, capacidade de retenção de água e perda de peso por cozimento, diferente do observado para a cor $\left(L^{*}, a^{*}\right.$ e $\left.b^{*}\right)$ e força de cisalhamento, que apresentaram diferença entre as marcas $(p \leq 0,05)$. Comparando-se os valores de $\mathrm{pH}$ e $\mathrm{L}^{*}$, pode-se sugerir que duas marcas avaliadas apresentaram características de carne normal, uma marca carne DFD $\left(\mathrm{pH}>6,0\right.$ e $\left.\mathrm{L}^{*}<45\right)$ e as outras duas PSE (pH $<6,0$ e $\mathrm{L}^{*}>50$ ). A pesquisa contribuiu para o levantamento de características consideradas importantes pelos consumidores de carne suína, sugerindo ações estratégicas para alcançar um maior índice de preferência e consumo. A avaliação dos parâmetros físicos das bistecas mostrou que, por se tratar amostras de diferentes procedências comerciais e submetidas a diferentes condições de processamento e armazenamento, existe uma variabilidade envolvida nos parâmetros físicos.

Palavras-chave: Atributos de qualidade. Carne DFD. Carne PSE. Comportamento de compra. Força de cisalhamento. Pesquisa descritiva.

\section{Introduction}

Pig farming is one of the most widespread agricultural activities in the world, pork being one of the most consumed animal proteins in various continents, representing great economic importance in several countries (THOMS et al., 2010). World pork production reached 111,650 million tons in 2015 and China is the leading producer, followed by the European Union and the United States. Pork production in Brazil in the same period was 3.63 million tons, the fourth largest producer in the world, representing $3.3 \%$ of the total production (ABPA, 2016).

In 2015, per capita pork consumption in Brazil $(15.1 \mathrm{~kg} /$ person/year) was lower than beef $(38.6$ $\mathrm{kg} /$ person/year) and poultry $(43.25 \mathrm{~kg} /$ person/ year) consumption, as the historical average of the last few years (ABIEC, 2016; ABPA, 2016) have demonstrated. According to Horta et al. (2010), the low consumption of pork in Brazil may be related largely to the myths related to possible deleterious effects of pork on consumer's health. Bezerra et al. (2007) and Falleiros et al. (2008) stated that the forming of a negative image associated to pork does exist in Brazil, resulting from a series of cultural and educational factors rooted in Brazilian society transmitted from one generation to the next without any scientific basis. This demonstrates the importance of evaluating consumer profile and the development of marketing actions to effectively break these paradigms.

In 2015, the State of Paraná was responsible for $21.47 \%$ of pig slaughtering in Brazil, behind only to Santa Catarina state (ABPA, 2016). Pork production has been present since the beginning of colonization, mainly in the Western Paraná region, when it was 
only a subsistence activity for the families and it later became a source of family income (HACK et al., 2011). Due to the importance of pork production and consumption in the country, and especially in the West of Paraná state, it is necessary to analyze the important aspects and attributes considered by the consumer at the time of purchase, in order to identify the consumer market demands. According to Zamberlan (2002), the concern and attention of the consumers on issues involving the foods characteristics are increasing. This has increased the concern of the industry, as well as all production chain agents to better understand consumers and meet their requirements and specifications.

Additionally, in order to concern about the sanitary safety standards of meat products, consumer behavior is influenced by health and nutrition issues described in labels. However, this information is not always available on in natura pork packs, marketed in butchers, meat shops or supermarkets. Most pork meat products are sold in bulk without detailed information at the time of cuts fractioning, making it difficult to characterize the product being purchased. It is extremely important for companies to know the consumers' preferences and needs through market research. It is a strategy used on investment risks reduction, establishing management, and minimizing mistakes with marketing plans for the product offered. Researchers aiming at identifying the most important characteristics of pork that influence consumer choice at the time of purchase are being carried out worldwide even today (NGAPO, 2017).

Among pork cuts, the steak is one of the most popular among consumers (BEZERRA et al., 2007; SILVA; SILVA, 2009), due to its practicality in preparation. Pork chop is a cut from the carré, obtained from the muscular masses adhered to the bony base of the pork loin; being considered a tenderer and leaner meat (ABCS, 2010). Thus, due to pork chops' popularity, the physical parameters that influence meat quality should be investigated. Data, in this sense, reinforce the characteristics of pork and serve as stimulus to its consumption.
The aim of this work was to develop a field research with professionals from the pig farming sector in conjunction with pork consumers living in municipalities located in the West of Paraná state, through questionnaires. The professionals answered questions related to pig farming developed in the region and consumers' answered questions regarding aspects, attributes, and relevant information at time of purchase, in order to characterize pork consumers in the region. The physical parameters of five commercial pork chop brands, produced and marketed by five different slaughterhouses located in the western region of Paraná were analyzed.

\section{Materials and Methods}

Pig farming related issues and the aspects and attributes survey considered by consumers in pork purchasing were evaluated by the application of an exploratory research, followed by a descriptive one. This study was authorized to collect responses from the respondents by the Ethics Committee of the Centro Educacional Integrado - CEI (Certificate of Ethical Evaluation Presentation 18624213.1.0000.0092, opinion 304.892).

After conducting the exploratory and descriptive research, the physical parameters of five commercial pork chop brands (A, B, C, D, and E) produced and marketed in the West of Paraná state were analyzed. The pork chops were purchased frozen from local commerce in the first semester of 2015 and kept frozen $\left(-18{ }^{\circ} \mathrm{C}\right)$ until the analysis. The samples were collected in triplicate and had been produced between one and two weeks prior.

\section{Exploratory research}

The aim was to collect information on pig farming situation and pork quality aspects. Two veterinarians, four entrepreneurs, and four pig farmers working in the West of Paraná state were interviewed. The questionnaire used is seen in Figure 1. 
Figure 1. Questionnaire of the exploratory research carried out with professionals in the pig farming (businessmen, veterinarians and pig farmers).

A) What sanitary care and safety attributes that pork must present to be consumed (certifications, vaccines, etc.)?

B) Regarding to animal welfare, what are the criteria adopted for producing quality meat?

C) What are the positives and negatives aspects of pork, which are taken into account at the time of purchase by consumers?

D) Regarding to pig farming, are there any prospects for new technologies?

E) Regarding to pig farming in the West of Paraná state, how is their growth in relation to production and the market?

F) What are the main problems and/or challenges faced by sector?

\section{Descriptive research}

It was performed with 100 pork consumers living in the West of Paraná state, using a questionnaire (Figure 2). The respondents were approached at supermarkets and butcheries in the municipalities of Itaipulândia, Missal, Medianeira, and São Miguel do Iguaçu in June/July 2013. The questionnaire was developed to identify the consumers' concerns regarding pork aspects and characteristics they considered most important at the time of purchase. 
Figure 2. Descriptive research questionnaire with pork consumers in the West of Paraná state.

\begin{tabular}{|c|c|c|}
\hline \multicolumn{3}{|c|}{ CHARACTERIZATION OF INTERVIEWEDS } \\
\hline \multicolumn{3}{|l|}{ A) Gender: } \\
\hline 1. ( ) Female & B) $\mathrm{A}$ & \\
\hline \multicolumn{3}{|l|}{ C) Level of education: } \\
\hline 1. ( ) Incomplete elementary school & \multicolumn{2}{|c|}{ 2. ( ) Complete elementary school } \\
\hline 3. ( ) Incomplete high school & \multicolumn{2}{|c|}{ 4. ( Complete high school } \\
\hline 5. ( ) Undergraduate & \multicolumn{2}{|c|}{ 6. ( ) Graduated } \\
\hline \multicolumn{3}{|l|}{ D) Marital status: } \\
\hline 1. ( ) Single & 2. ( ) Married & 3. ( ) Widower \\
\hline 4. ( ) Separated/divorced & 5. ( ) Other & \\
\hline \multicolumn{3}{|l|}{ E) Family income: } \\
\hline \multicolumn{3}{|l|}{ 1. ( ) Up to 1 minimum wage } \\
\hline \multicolumn{3}{|l|}{ 2. ( ) From 1 to 2 minimum wage } \\
\hline \multicolumn{3}{|l|}{ 3. ( ) From 2 to 3 minimum wage } \\
\hline \multicolumn{3}{|l|}{ 4. ( ) From 3 to 4 minimum wage } \\
\hline \multicolumn{3}{|l|}{ 5. ( ) Above to 4 minimum wage } \\
\hline
\end{tabular}

\section{CONSUMER PORK MEAT PREFERENCE}

A) As consumer, what is your preference about meat:
1. ( ) Poultry
2. ( ) Beef
3. ( ) Fish
4. ( ) Pork
5. ( ) Other. What,?

B) Are you a pork consumer?

1. ( ) Yes 2. ( ) No

C) If YES, how often do you

consume?

$\begin{array}{lll}\text { 1. ( ) Daily } & \text { 2. ( ) } 1 \text { time a week } & 3 \text {. ( ) } 2 \text { to } 3 \text { times a week }\end{array}$

4. ( ) 1 time every 2 week

5. ( ) 1 time a month

6. ( ) Do not consume

7. ( ) Other. How often?

D) What is the method of preparation?
1. ( ) Roasted
2. ( ) Fried
3. ( ) Cooked
4. ( ) Other. What?

E) What is your favorite cut?
1. ( ) Pork chop
2. ( ) Rack
3. ( ) Pork rib
7. ( ) Other. Which?
4. ( ) Loin
5. ( ) Pork leg
6. ( ) Pork shoulder

F) Evaluate the importance of the general aspects of pork that you consider important at the purchase time:

1. Unimportant
4. Important

1. Price

2. Brand

3. Federal inspection register

(FIR)

4. Expiration date

5. Nutritional composition

6. Fat content

7. Cut

8. Package
2. Little important

5. Very important

1. ( ) 2.(

1. ( ) 2.( )

1. ( ) 2.( )

1. ( ) 2.( )

1.( ) 2.( )

1. ( ) 2.( $)$

1. ( ) 2.( )

1. ( ) 2.( )
3. Indifferent

3. ( )
3. ( )
3. ( )
3. ( )
3. ( )
3. ( )
3. ( )
3. ( )

4. ( )

4. ( )

4. ( )

4. ( )

4. ( )

4. ( )

$4 .($

4. ( )

$5 .(\quad)$
$5 .(\quad)$
$5 .(\quad)$
$5 .(\quad)$
$5 .(\quad)$
$5 .(\quad)$
$5 .(\quad)$
$5 .()$

G) Regarding the sensory aspects of pork, list each of these attributes according to the importance order at the purchase time of the product:

$\begin{array}{lllll}\text { 1. ( ) Aroma } & \text { 2. ( ) Flavor } & \text { 3. ( ) Color } & \text { 4. ( ) Texture } & \text { 5. ( ) Juiciness }\end{array}$ 
The importance of pork aspects considered by consumers at the time of purchase was assessed on a scale of 1 to 5 ("from unimportant to "very important"). The evaluated aspects were: price, brand, federal inspection register (FIR), expiration date, nutritional composition, fat content, cut, and packaging. The sensory related attributes; aroma, flavor, color, texture, and juiciness were ordered according to their degree of importance. The average level of importance for each aspect or overall attribute was calculated to facilitate data comprehension. The values were obtained by converting the scale of importance ( 1 to 5 ) into percentage values, where each point of the scale was multiplied by $20 \%(1=20 \%, 2=40 \%, 3=$ $60 \%, 4=80 \%$ e $5=100 \%)($ ZAMBERLAN, 2002).

\section{Determination of pork chops physical parameters}

The $\mathrm{pH}$ was measured in triplicate using the contact potentiometer (Texto, 205 model, Campinas, Brazil) as described by Soares et al. (2002) and Oda et al. (2003).

Water retention capacity (WRC) determination was performed in triplicate according to Hamm (1960). The sample was weighed $(2.00 \pm 0.10 \mathrm{~g})$ (P1) and placed between two paper filters, and these placed between two acrylic plates, on which a $10 \mathrm{~kg}$ weight was placed for $5 \mathrm{~min}$. The sample was weighed once again (P2) and the WRC was calculated and expressed as exuded water percentage according to the WRC $(\%)=100-(\mathrm{P} 1-\mathrm{P} 2) / \mathrm{P} 1$ * 100 equation.

Weight loss upon cooking (WLC) was performed by weighing pork chop samples before (P1) and after cooking (P2) in an electric oven (Fisher, Hot Grill 10537-13368 model, Brusque) preheated at $250{ }^{\circ} \mathrm{C}$ for $40 \mathrm{~min}$ until the temperature in the geometric center of the product reached a minimum $85{ }^{\circ} \mathrm{C}$. WLC was performed in triplicate and calculated according to WLC $(\%)=(\mathrm{P} 1-\mathrm{P} 2) / \mathrm{P} 1$ * 100 equation.
Color measurements were performed on the surface of the samples, taking five different reading points per sample, using the colorimeter (Konica Minolta, CR400, Ramsay, USA) with an integrating sphere and a $45^{\circ}$ viewing angle $(\mathrm{d} / 45$ illumination and $\mathrm{D}$ illuminant). The luminosity $\left(\mathrm{L}^{*}\right)$, red-green component $\left(\mathrm{a}^{*}\right)$, and yellow-blue component $\left(\mathrm{b}^{*}\right)$ values were obtained.

The instrumental measurement of the texture was performed using a texturometer (Stable Micro System, TA.XT/Plus/50 model, Godalming, UK) with a $5 \mathrm{~kg}$ calibration load cell. The samples were cooked following the WLC procedure and the pieces were standardized $\left(1 \times 1 \times 2 \mathrm{~cm}^{3}\right)$. The shearing force was determined using the Probe WarnerBratzler (HDP/WBV) (pre-test speed: $5.0 \mathrm{~mm} \mathrm{sec}^{-1}$; test speed: $2.0 \mathrm{~mm} \mathrm{sec}^{-1}$; post-test velocity: $5.0 \mathrm{~mm}$ $\mathrm{sec}^{-1}$; sample distance: $25 \mathrm{~mm}$; sample penetration distance: $30 \mathrm{~mm}$; and applied force: $25 \mathrm{~g}$ ). Ten measurements were taken for each sample and the results were expressed in $\mathrm{kg}$ for the maximum force required to cut the samples.

The data were submitted to variance analysis (ANOVA), Tukey test, $(\mathrm{p} \leq 0.05)$, and Principal Component Analysis (PCA) using STATISTICA 7.0 (Statsoft Inc., Tulsa, USA) software.

\section{Results and Discussion}

\section{Exploratory research}

$40 \%$ of respondents mentioned the importance of preventive vaccination, emphasizing the importance on the number of applications, doses, and vaccines validity. In addition, the importance of medicines administration that did not interfere with the meat quality was reported, reinforcing the need to abide to the grace period before the animal slaughter.

Regarding the criteria adopted to produce quality meat and for animal welfare, $60 \%$ of respondents emphasized the importance of pre-slaughter management care. They reinforced the care during transportation, loading and unloading, farm 
management, quality of food offered, and respect of the water intake. These pieces of information suggest that pig professionals understand the market demands for animal welfare offering quality healthrisk-free products to consumers.

When questioned about the positive and negative aspects of pork considered at the time of purchase, an affordable cost was one of the most mentioned positive aspects, followed by appearance and flavor. The lack of information on labels was highlighted by the respondents as a negative point when considering the meats in general. Despite the trading of meat in bulk in its respective commercial packaging, the commercialization of cut fractions without a label, nutritional information, and other relevant information at the point of sale is a problem faced by consumers.

Regarding the prospects for the employing of new technologies in pig farming, the respondents mentioned the introduction of new cuts, the acquisition of new pork products, and the genetic enhancement of animals.

Regarding the swine market growth situation in the West of Paraná state, the interviewed (40\%) mentioned that some municipalities have already reached their production limit. One veterinarian mentioned that "production in West of Paraná is highly technified, but it is already surpassing its market's absorption capacity." This may be related to the pig production demand, reaching good production rates. On the other hand, the concentration of pig farming in the municipalities of the West of Paraná state may have a high pollution potential, due to the waste produced. In some municipalities where the research was carried out, such as Missal, for instance, it was reported that there is no longer a proportion of land for the implementation of new breeding farms since the waste produced has reached the water supply source. Other municipalities, such as Itaipulândia, are nearly reaching their limit, making environmental licensing to validate the operation of the farms a necessity. Therefore, environmental actions for waste control should be studied and applied.

Regarding the main problems and challenges faced in the pig farming sector today, the meat price fluctuation was highlighted by pig farmers. The instability in production and price variation lead to fluctuations in prices paid by importers. In addition, the interviewed mentioned the need to add value to the final product and secure new markets by introducing new cuts. These factors may influence pork supply and demand, as well as the quality of the end product.

\section{Descriptive research}

Among the consumers interviewed, $42 \%$ lived in the municipality of Medianeira, 23\% in Missal, 20\% in Itaipulândia, and $15 \%$ in São Miguel do Iguaçu. Females accounted for $60 \%$ of consumers. Their age ranged from 17 to 57 years, with $24 \%$ of consumers aged between 21 and 24. Most respondents were either graduated $(46 \%)$ or undergraduates $(45 \%)$. The education level is a factor that may be largely related to the level of information demanded by consumers. As for marital status, $48 \%$ of consumers were married and $46 \%$ were single.

The majority of the respondents $(82 \%)$ had a family income above two national minimum wages, with $30 \%$ of those interviewed reporting an income above four national minimum wages. Income is a factor that can interfere in the consumption of certain foods, depending on the price and on the purchasing power for each family. There was great diversity among the respondents in terms of professional qualifications.

Although all respondents declared themselves to be pork consumers, $60 \%$ indicated they preferred beef, $28 \%$ poultry, $10 \%$ fish, and $2 \%$ pork (Figure 3). Similar results were found by Cavalcante Neto (2003), Souza (2007), Falleiros et al. (2008), Silva and Silva (2009), and Santos et al. (2011) who developed research with consumers questioning 
their meat consumption preferences. In all cases cited, beef was mentioned as the preferred one, followed by poultry, pork, and fish. These results may be correlated with the myths and preconception involving pork, unconsciously present in the preferences and habits of Brazilian consumers. Falleiros et al. (2008) comment that despite the constant evolution in the process of obtaining pork, resulting in lower fat and cholesterol contents, being an important source of proteins and B complex vitamins, there is still intrinsic preconception from consumers who consider pork a "highly-fatty", "highly-caloric" or "source of disease" food, such as cysticercosis.

Although most consumers did not consider pork as their preference, $56 \%$ declared to consume it 2 to 3 times a week (Figure 3). Since the West of Paraná state has a significant pork production, it results in more affordable prices compared to beef, making it a regular staple food for most consumers.

Bezerra et al. (2007) reported that in the microregion of Campina Grande, Paraiba state, only $24.44 \%$ of consumers eat pork 2-3 times per week, representing an index lower than the one mentioned in the present study. Souza (2007) reported that in the city of Pelotas, Rio Grande do Sul state, 48.5\% of the respondents reported consuming pork 2-5 times a month, 5.4\% daily, and 33.9\% monthly. Thoms et al. (2010) interviewed high school students from the town of Irati, Paraná state, stated consuming pork once a week or more $(41 \%)$, once a month (16\%), and $17 \%$ said they did not consume it at all. In the present study, consumers reported a higher consumption frequency in relation to the above-cited authors, reinforcing the more affordable price hypothesis in the region favors consumption, although the preference for this type of meat is lower.

Among the forms of pork preparation most commonly used by consumers, 49\% mentioned consuming fried pork (Figure 3). This form of preparation is related to practicality at the time of consumption. There is a growing pursuing for quick meals consumption, and frying is an alternative. However, $45 \%$ of respondents mentioned preferring the consumption of roasted pork, regardless of practicality, as many of these consumers are concerned about health and avoid fried meat meals.

Consumers were asked about the most consumed pork cut. Pork chops and ribs were the preferred ones, both cited by $36 \%$ of consumers, followed by pork legs with $13 \%$ of the preferences (Figure 3 ). These results demonstrate that consumers prefer more practical cuts such as pork chops and ribs, usually consumed roasted or fried.

Similarly, Bezerra et al. (2007) demonstrated the preference for pork chops $(52.3 \%)$ and ribs $(27.5 \%)$ in the micro-region of Campina Grande, Paraíba state. Silva and Silva (2009) reported that pork chop was the preferred cut $(33 \%)$ in the city of Guarabira, Paraíba state. Souza (2007) verified in the city of Pelotas, Rio Grande do Sul state, most consumers prefer pork loin (61.4\%), followed by ribs $(43.0 \%)$, and pork leg $(37.7 \%)$. In a study performed by Antonangelo et al. (2011) in the city of Botucatu, São Paulo state, $27.7 \%$ of consumers stated consuming all pork cuts, $16.6 \%$ pork chops and loin, and 5.5\% ribs and pork leg. These results demonstrate that the preference for a meat cut is related to regional consumption habits.

The expiration date was the most important aspect considered by the consumers interviewed (87\%), representing $95.4 \%$ of average importance. The federal inspection register label (FIR) appears as the second most important item, highlighted by $61 \%$ of consumers and representing $86.2 \%$ of the average importance level of the attributes (Table 1). Bezerra et al. (2007) reported that 36\% of consumers preferred products with FIR label; $32.75 \%$ consumed products uncontrolled by FIR; $18 \%$ did not know what FIR was, and $13.25 \%$ did not care if the product was inspected or not. The results demonstrate the concern of the consumers interviewed in this study for certified products with quality assurance. 
Figure 3. Consumer preference regarding meat type, frequency of pork consumption, preparation method and preferred cut.

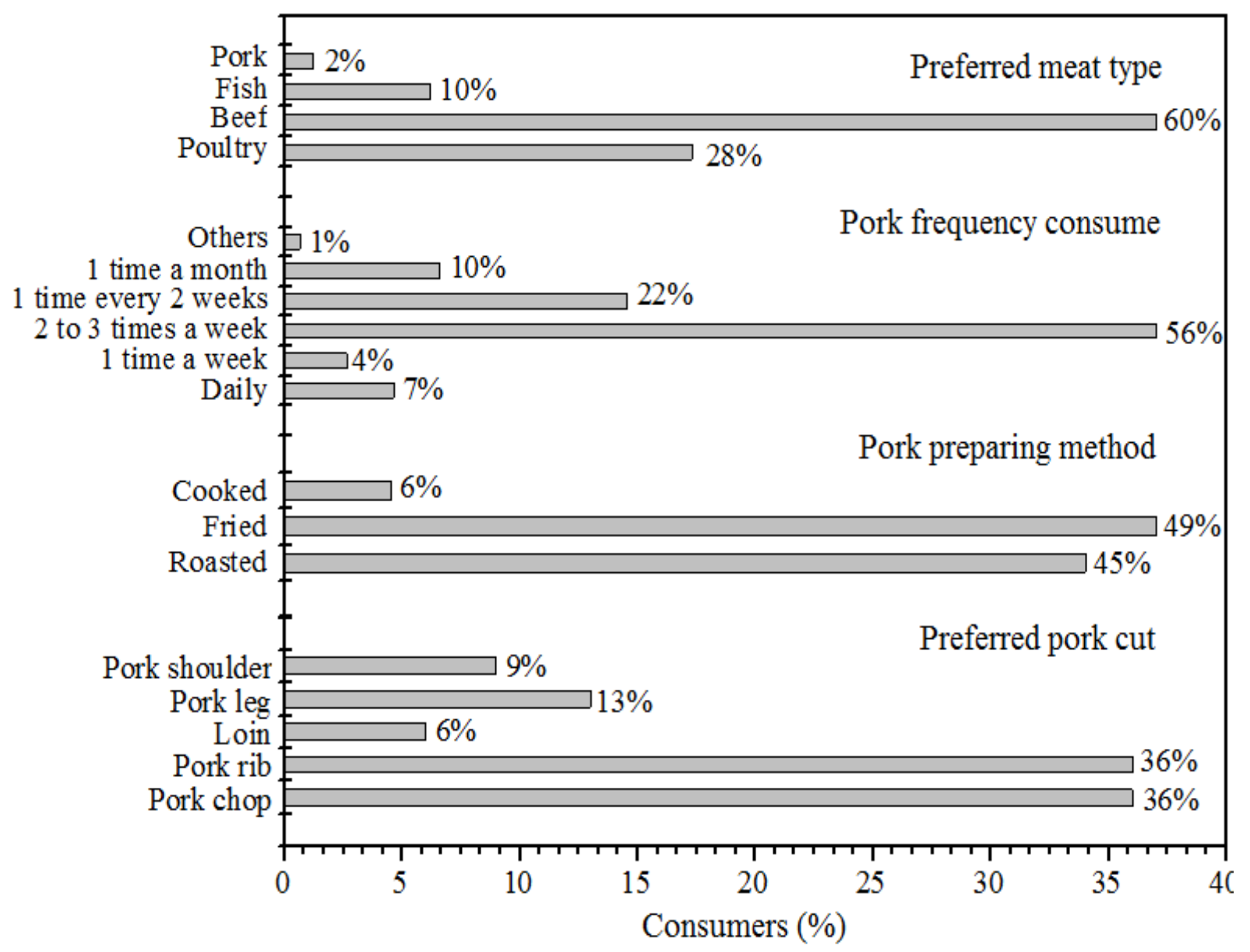

Table 1. Degree of importance of the general aspects considered during the purchase.

\begin{tabular}{lcccccc}
\hline General aspects & Unimportant & $\begin{array}{c}\text { Little } \\
\text { important }\end{array}$ & Indifferent & Important & $\begin{array}{c}\text { Very } \\
\text { important }\end{array}$ & $\begin{array}{c}\text { Importance } \\
\text { average } \\
\text { level }\end{array}$ \\
\hline Price & $10 \%$ & $10 \%$ & $11 \%$ & $46 \%$ & $23 \%$ & $58.4 \%$ \\
Brand & $8 \%$ & $20 \%$ & $16 \%$ & $33 \%$ & $23 \%$ & $68.6 \%$ \\
Federal inspection register (FIR) & $6 \%$ & $4 \%$ & $4 \%$ & $25 \%$ & $61 \%$ & $86.2 \%$ \\
Expiration date & $3 \%$ & $0 \%$ & $1 \%$ & $9 \%$ & $87 \%$ & $95.4 \%$ \\
Nutritional composition & $4 \%$ & $12 \%$ & $26 \%$ & $36 \%$ & $22 \%$ & $72.0 \%$ \\
Fat content & $3 \%$ & $10 \%$ & $19 \%$ & $38 \%$ & $30 \%$ & $76.4 \%$ \\
Cut & $5 \%$ & $11 \%$ & $20 \%$ & $45 \%$ & $19 \%$ & $72.4 \%$ \\
Package & $6 \%$ & $7 \%$ & $16 \%$ & $35 \%$ & $36 \%$ & $77.6 \%$ \\
\hline General assessment of the pork & & & & & & $75.9 \%$ \\
aspects & & & & & & \\
\hline
\end{tabular}


Packaging had a $77.6 \%$ average level of importance mentioned by $36 \%$ of consumers as very important and 35\% as important, representing the third most important aspect. The results point to the influence of packaging on consumer preference, suggesting that consumers are aware of their importance for product quality assurance.

The fat contents was the fourth most important item, with a $76.4 \%$ level of importance, mentioned by $30 \%$ of consumers as very important and by $38 \%$ as important. It suggests that the meat cut aspect regarding the fat contents is taken into account by consumers at the time of purchase, especially when the consumer prefers lean cuts.

The cut represented a $72.4 \%$ average level of importance, close to the level of importance of the nutritional composition $(72.0 \%)$. Bezerra et al. (2007) pointed out that $65.5 \%$ of consumers interviewed declared that they were not well informed about the nutritional composition of pork. Antonangelo et al. (2011) pinpointed that the majority of pork consumers are unaware of its nutritional characteristics. These factors point to the lack of knowledge about the nutritional attributes of pork and the lower preference in relation to other types of meat, justifying the performance of more marketing actions by the industry.

Brand was the second least important factor, considering that it reached an average importance level of $68.6 \%$. The price represented $58.4 \%$ of average importance level, being considered an aspect of minor importance at the time of purchase. These results demonstrated consumers look for aspects related to the product that go beyond economic value and brand, quote the quality. In contrast, Bezerra et al. (2007) found that when choosing and buying pork, the price was the most important factor, mentioned by $36.7 \%$ of consumers.

Figure 4 shows a comparison between the averages of aspects considered important by consumers at the time of purchase compared to the general importance average $(75.9 \%)$. It can be noted that the importance of expiration date (95.4\%) and of the FIR label (86.2\%) stand out in relation to the general importance average. In addition, it is observed that price $(58.4 \%)$ is of less importance than the average of general importance.

Table 2 shows the importance of color compared to the other sensorial attributes, followed by texture and aroma. The color indication suggests that the consumer correlates the appearance of the meat with the quality of the end product, which may interfere in the purchase intention.

Juiciness and flavor were the sensory attributes considered less important by consumers at the time of purchase. The fact that the evaluation of these attributes cannot be performed at time of purchase may have contributed to these results. However, it is emphasized that the sensorial perception of the product by consumers after the time of purchase is a factor that will determine whether or not they will purchase the product or brand in question again. 
Figure 4. Average importance of aspects $\mathrm{x}$ average of general importance.

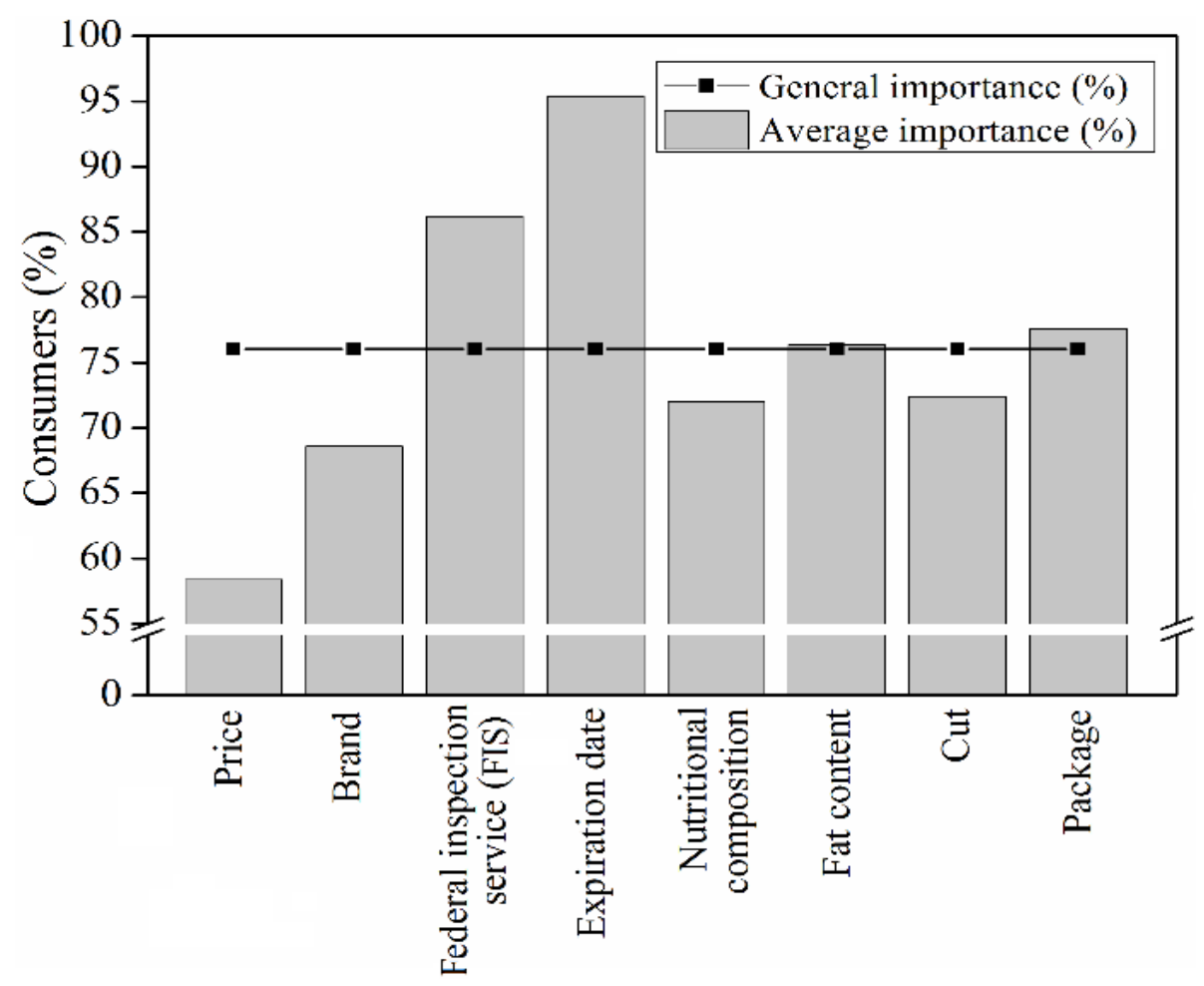

Table 2. Importance order of the pork sensorial attributes considered by consumers at the time of purchase.

\begin{tabular}{lcccccc}
\hline \multirow{2}{*}{ Sensory attribute } & \multicolumn{5}{c}{ Importance order } & \multirow{2}{*}{ Importance average level } \\
\cline { 2 - 5 } & 1 & 2 & 3 & 4 & 5 & \\
\hline Aroma & $13 \%$ & $26 \%$ & $33 \%$ & $14 \%$ & $14 \%$ & $62.0 \%$ \\
Flavor & $11 \%$ & $11 \%$ & $18 \%$ & $28 \%$ & $32 \%$ & $48.2 \%$ \\
Color & $61 \%$ & $18 \%$ & $6 \%$ & $9 \%$ & $6 \%$ & $83.8 \%$ \\
Texture & $9 \%$ & $38 \%$ & $31 \%$ & $16 \%$ & $6 \%$ & $65.6 \%$ \\
Juiciness & $6 \%$ & $7 \%$ & $12 \%$ & $33 \%$ & $42 \%$ & $40.4 \%$ \\
\hline
\end{tabular}

\section{Physical parameters of pork chops}

According to the descriptive research results, despite the popularity of pork and it being consumed by all consumers interviewed, there is still some resistance to their preference compared to other types of meat. Thus, studies that reinforce the quality parameters of pork are important in order to increase their consumption. Pork chop was evaluated by physical parameters as it was one of the pork cuts most preferred by consumers (36\%). Table 3 presents the results of the physical analyses performed on pork chops, as well as the ANOVA and Tukey test values. 
Table 3. Physical analyzes performed on pork chops from different brands.

\begin{tabular}{ccccccc}
\hline \multirow{2}{*}{$\begin{array}{c}\text { Physical } \\
\text { parameters }\end{array}$} & $\mathrm{A}$ & $\mathrm{B}$ & $\mathrm{C}$ & $\mathrm{D}$ & \multirow{2}{*}{ Commercial brands } \\
\cline { 2 - 6 } $\mathrm{nH}$ & $6.2 \pm 0.2$ & $5.8 \pm 0.2$ & $5.9 \pm 0.1$ & $6.0 \pm 0.2$ & $6.0 \pm 0.2$ & \\
\hline $\mathrm{L}^{*}$ & $43.25^{\mathrm{b}} \pm 2.28$ & $49.66^{\mathrm{a} b} \pm 2.49$ & $52.16^{\mathrm{a}} \pm 3.35$ & $44.94^{\mathrm{b}} \pm 1.67$ & $52.45^{\mathrm{a}} \pm 1.77$ & 0.11 \\
$\mathrm{a}^{*}$ & $6.20^{\mathrm{c}} \pm 0.41$ & $17.35^{\mathrm{a}} \pm 0.89$ & $13.22^{\mathrm{b}} \pm 2.04$ & $9.20^{\mathrm{c}} \pm 1.04$ & $8.80^{\mathrm{c}} \pm 1.57$ & $0.00005^{*}$ \\
$\mathrm{~b}^{*}$ & $8.25^{\mathrm{c} \cdot \mathrm{d}} \pm 1.27$ & $13.96^{\mathrm{a}} \pm 0.59$ & $11.52^{\mathrm{a} . \mathrm{b}} \pm 1.72$ & $7.39^{\mathrm{d}} \pm 1.00$ & $10.74^{\mathrm{b}} \pm 0.77$ & $0.0002^{*}$ \\
WRC (\%) & $30.8 \pm 0.2$ & $32.5 \pm 1.6$ & $36.6 \pm 3.1$ & $33.4 \pm 0.3$ & $32.1 \pm 1.1$ & 0.08 \\
WLC (\%) & $23.1 \pm 0.6$ & $25.4 \pm 1.6$ & $25.4 \pm 1.6$ & $22.4 \pm 2.6$ & $27.5 \pm 3.3$ & 0.09 \\
Shearing force $(\mathrm{kg})$ & $3.47^{\mathrm{b}} \pm 0.24$ & $6.58^{\mathrm{a}} \pm 0.67$ & $3.15^{\mathrm{b}} \pm 0.42$ & $5.34^{\mathrm{a} . \mathrm{b}} \pm 1.41$ & $4.22^{\mathrm{b}} \pm 0.83$ & $0.003^{*}$ \\
\hline
\end{tabular}

Means followed by different letters in the same row indicate significant differences by Tukey test $(\mathrm{p} \leq 0.05)$.

The $\mathrm{pH}$ of pork chop samples ranged from 5.8 (brand B) to 6.2 (brand A), with no significant difference between samples $(\mathrm{p}>0.05)$. Hansen et al. (2004) reported final $\mathrm{pH}$ values (24 h postmortem) ranging from 5.53 to $6.32(\mathrm{n}=6)$, for pork chops that followed the same handling and slaughtering conditions. Despite the variability of pork chop sources purchased from local commerce in the West of Paraná state, the values did not suffer many variations as observed by the aforementioned author.

Brand E presented the highest L* (52.45) value, similar to brand C (52.16) ( $p>0.05)$, and different from brand A (43.25) and D (44.94) $(\mathrm{p} \leq 0.05)$, which presented the lowest values. Brand B presented an intermediate value (49.66), not differing from any brand $(\mathrm{p}>0.05)$. Meat $\mathrm{pH}$ and color determinations are important parameters for the evaluation of their properties.

According to Channon et al. (2000), three characteristics for pork are defined depending on color and $\mathrm{pH}$ parameters: normal for $\mathrm{pH}<6.0$ and $\mathrm{L}^{*}<50$; pale, soft, and exudative (PSE) for $\mathrm{pH}<$ 6.0 and $\mathrm{L}^{*}>50$ and; dark, firm, and dry (DFD) for $\mathrm{pH}>6.0$ and $\mathrm{L}^{*}<42$. In the study developed by Maganhini et al. (2007), L* values $>53$ are considered PSE; $<45$ as DFD, and between 45 and 53 as normal. Considering the classification of Channon et al. (2000), comparing $\mathrm{pH}$ and $\mathrm{L}^{*}$ results for each brand analyzed, brands $\mathrm{C}$ and $\mathrm{E}$ would be considered PSE $\left(\mathrm{pH}<6.0\right.$ and $\left.\mathrm{L}^{*}>50\right)$, brand A DFD ( $\mathrm{pH}>6.0$ and $\left.\mathrm{L}^{*}<45\right)$, while brands $\mathrm{B}$ and D would be considered normal. However, it should be noted that the analyzed samples were frozen at the point of sale and were subjected to thawing for the determinations. Even under controlled thawing conditions as applied in the present study $(6 \pm 1$ ${ }^{\circ} \mathrm{C} / 12 \mathrm{~h}$ ), changes in the physical properties of the meat can occur, and to confirm these hypotheses, performing the determinations in $24 \mathrm{~h}$ post-mortem fresh meat would be ideal.

Observing $\mathrm{L}^{*}$ and $\mathrm{pH}$ values distribution histograms (Figure 5), there was a great variability of the obtained data; that can be explained by the differences between the pork chop brands, involving the slaughter of different pig breeds and also applying different processing steps. The presence of samples at the two extremes of $\mathrm{L}^{*}$ value, associated with $\mathrm{pH}$, suggests the presence of DFD and PSE meat, similar to that observed by Maganhini et al. (2007). 
Figure 5. Histogram of distribution of $\mathrm{L}^{*}$ (a) and $\mathrm{pH}(\mathrm{b})$ values for the pork chops.

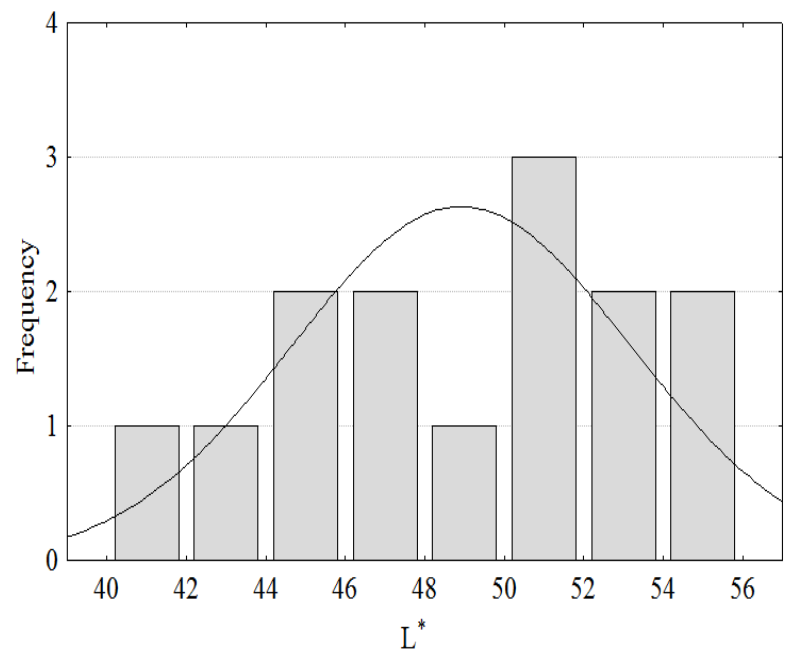

(a)

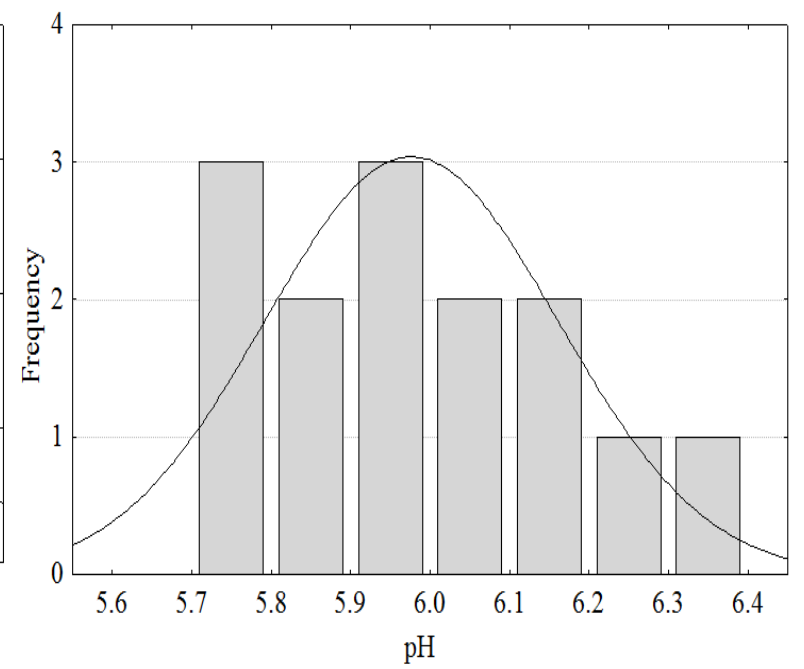

(b)
A negative correlation $(\mathrm{R}=-0.35)$ was observed between $\mathrm{pH}$ and $\mathrm{L}^{*}$ values from all the samples evaluated. This correlation indicates that lower $\mathrm{pH}$ values lead to higher $\mathrm{L}^{*}$ values, a fact that is explained by protein denaturation resulting in greater reflected light (JUNCHER et al., 2001). However, the correlation was not significant at $95 \%$ confidence level $(p=0.13)$, and it may be related to the origin variability of the studied meats.

The $\mathrm{a}^{*}$ value was higher for brand $\mathrm{B}(17.35)$ and different from $C(13.22)(p \leq 0.05)$. Brands $\mathrm{B}$ and $\mathrm{C}$ were different from brands A (6.20), D (9.20), and $E(8.80)$ and the last three were similar to each other $(\mathrm{p}>0.05)$. According to Maganhini et al. (2007), differences were not observed for a* in Longissimus dorsi samples from pigs slaughtered in a commercial slaughterhouse, with values lower than those obtained in the present study (1.15 to 1.34).

For $\mathrm{b}^{*}$ values, brand $\mathrm{B}$ presented the highest value (13.96), different from A (8.25), D (7.39), and E (10.74) $(\mathrm{p} \leq 0.05)$ and similar to $C(11.52)(\mathrm{p}>$ $0.05)$. The $b^{*}$ value of brand $C$ was similar to the one observed for $\mathrm{E}$ and $\mathrm{A}$. Brand D had the lowest $\mathrm{b}^{*}$ value and was similar to brand A. Maganhini et al. (2007) observed higher $b^{*}$ values in PSE (8.48), normal (7.93), and DFD (6.37) pork loin samples.
Hansen et al. (2004) reported $b^{*}$ values between 11.5 and 9.5 for pork chops with $\mathrm{pH} 24 \mathrm{~h}$ postmortem and between 5.5 and 6.3 for pork chops stored frozen for 6 days. The authors mentioned that $\mathrm{pH}$ can influence $\mathrm{b}^{*}$ value, being higher in samples with lower $\mathrm{pH}$.

WRC (\%) and WLC (\%) values were not significantly different $(\mathrm{p}>0.05)$ among the brands analyzed, ranging from 30.8 to 36.6 for WRC and from 22.4 to 27.5 for WLC.

In terms of shearing force $(\mathrm{kg})$, brand B presented the highest value (6.58), different from brands $\mathrm{A}$ (3.47), C (3.15) and E (4.22). Brand D presented an intermediate value (5.34) but did not differ $(p>0.05)$ from the others. The values obtained were close to those reported by Channon et al. (2000) for Longissimus dorsi (4.26 to $5.59 \mathrm{~kg}$ ) samples stored for 5 days, depending on the slaughtering operational conditions.

To evaluate the pork chops physical parameters according to the brands studied, the principal components analysis (PCA) was performed. PC1, PC2, and PC3 were the selected components, explaining $75.6 \%$ of the variability (Table 4 and Figure 6). A positive correlation between WRC and $\mathrm{pH}$ and between WLC and $\mathrm{L}^{*}$ values was observed at the same time as the inverse relationship between 
WRC and $\mathrm{pH}$ in relation to WLC and $\mathrm{L}^{*}$ (Figure $6 \mathrm{a})$. When the meat presents $\geq 6.0 \mathrm{pH}$ values the interaction between proteins and water are favored by the distance of the isoelectric point of the proteins. This type of meat tends to have higher WRC, therefore, presenting lower $\mathrm{L}^{*}$ and WLC values. The samples dispersion allowed to identify that brands $\mathrm{A}$ and $\mathrm{D}$ had an inverse relation with brands $\mathrm{C}$ and $\mathrm{E}$ in the same quadrants of $\mathrm{pH}, \mathrm{WRC}, \mathrm{WLC}$, and $\mathrm{L}^{*}$ physical parameters (Figure 6c), corroborating with the considerations on PSE, DFD, and normal meat characterizations. Furthermore, it was observed that brands $\mathrm{C}$ and $\mathrm{E}$ had similar behavior, being positioned in the same quadrant (Figure $6 \mathrm{c}$ and $\mathrm{d}$ ). The variability of the results obtained according to the brands, as previously reported, can also be visualized by the PCA.

Table 4. Principal components (PC) and percentage of variance explained by the components in the physical parameters of pork chops from different brands (A, B, C, D and E).

\begin{tabular}{cccc}
\hline Principal component & Eigenvalues & \% of total variation & \% of cumulated variation \\
\hline PC1 & 2.57 & 35.34 & 35.34 \\
PC2 & 1.59 & 22.64 & 57.98 \\
PC3 & 1.23 & 17.62 & 75.61 \\
PC4 & 0.86 & 12.30 & 87.91 \\
PC5 & 0.54 & 7.76 & 95.66 \\
PC6 & 0.25 & 3.35 & 99.02 \\
PC7 & 0.07 & 0.98 & 100.00 \\
\hline
\end{tabular}

Figure 6. Projection of the pork chop physical parameters obtained for brands A, B, C, D and E (a and b) and commercial brands on the factorial plan (c and d).

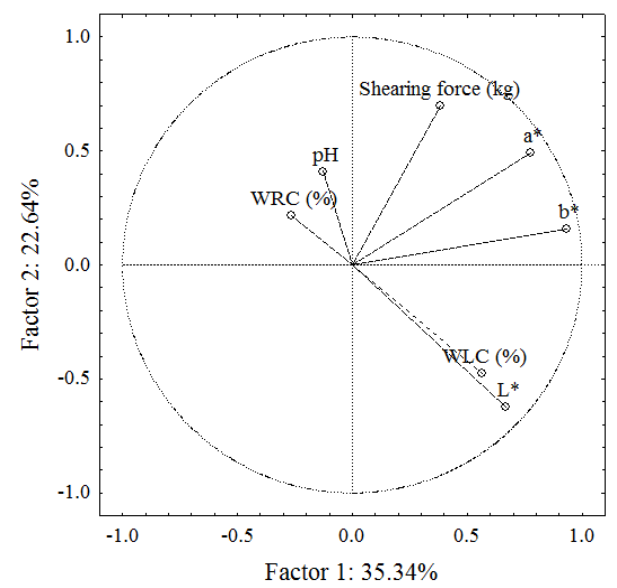

(a)

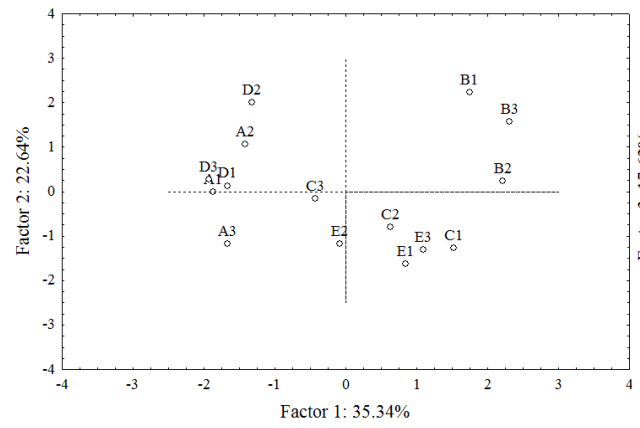

(c)

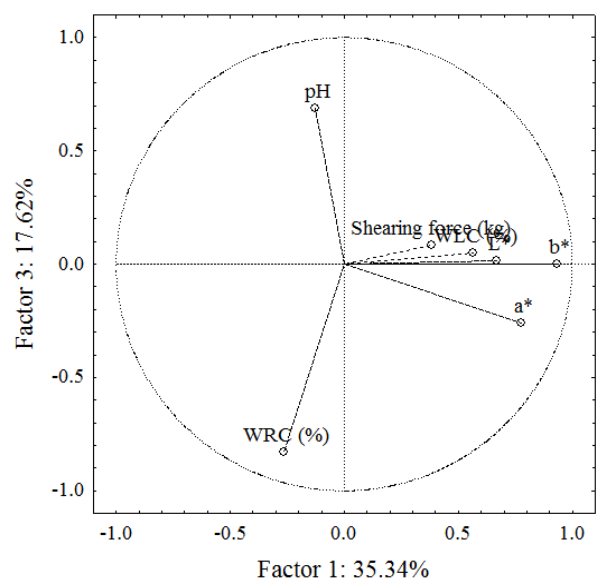

(b)

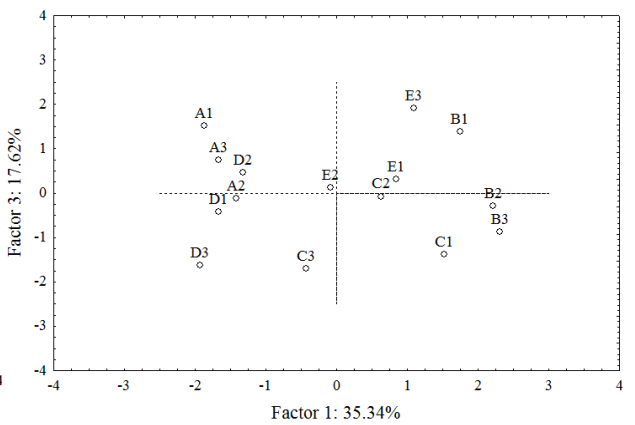

(d) 


\section{Conclusion}

Regarding the pork production process as a whole, focusing on meat quality, environmental issues, and the inability to absorb the pig production market in the region are topics of great relevance to pig farming sector professionals of the West of Paraná state.

Although beef is preferred, $52 \%$ of consumers eat pork 2-3 times a week, possibly due to the law of supply and demand. Pork chops and ribs were the favorite cuts, consumed fried or roasted. The expiration date and federal inspection register (FIR) were the most important aspects at the time of purchase, while price was the least important, justifying the consumers' interest in certified quality meats. Color, texture, and aroma sensory attributes were the most important ones. The pork chop samples had different origins, which generated a great variation in the physical parameters, with the identification of normal, PSE, and DFD meat characteristics, without compromising the safety of the product.

The results allowed to evaluate consumer behavior and to conclude that strategic actions by industries, producers, and the media, in general, can emphasize the benefits of pork consumption and quality, promoting a higher per capita consumption in the country and that such measures are necessary to standardize the quality of cuts.

\section{References}

ANTONANGELO, A.; RUV, C.; BUONANNO, J. D.; RIBEIRO, N. M.; DOLAZZA, R. M. Perfil dos consumidores de carne suína no Município de Botucatu - SP. Tékhne e Lógos, Botucatu, v. 2, n. 2, p. 20-29, 2011.

ASSOCIAÇÃO BRASILEIRA DAS INDÚSTRIAS EXPORTADORAS DE CARNES - ABIEC. Relatório anual ABIEC - Perfil da pecuária brasileira 2016. São Paulo: ABIEC, 2016. Disponível em: <http://www. newsprime.com.br/img/upload2/2016_FolderPerfil_ PT.pdf>. Acesso em: 25 abr. 2017.
ASSOCIAÇÃO BRASILEIRA DE CRIADORES DE SUÍNOS - ABCS. Manual brasileiro de cortes suínos. Brasília: ABCS, 2010. 56 p. Disponível em: $<$ http:// www.abcs.org.br/manual-de-cortes>. Acesso em: $25 \mathrm{abr}$. 2017.

ASSOCIAÇÃO BRASILEIRA DE PROTEÍNA ANIMAL - ABPA. Relatório Anual ABPA 2016. São Paulo: ABPA, 2016. Disponível em: <http://abpa-br.com. br/storage/files/versao_final_para_envio_digital_1925a final_abpa_relatorio_anual_2016_portugues_web1. pdf>. Acesso em: 25 abr. 2017.

BEZERRA, J. M. M.; CAVANCANTE NETO, A.; SILVA, L. P. G.; LUI, J. F.; RODRIGUES, A. E.; MARTINS, T. D. D. Caracterização do consumidor e do mercado da carne suína na microrregião de Campina Grande, estado da Paraíba. Ciência Animal Brasileira, Goiânia, v. 8, n. 3, p. 485-493, 2007.

CAVALCANTE NETO, A. A caracterização, avaliação $e$ estratégias de desmistificação dos consumidores e do mercado da carne suína no Estado da Paraíba. 2003. Monografia (Trabalho de Conclusão de Curso de Graduação em Zootecnia) - Centro de Ciências Agrárias. Universidade Federal da Paraíba, Areia.

CHANNON, H. A.; PAYNE, A. M.; WARNER, R. D. Halothane genotype, pre-slaughter handling and stunning method all influence pork quality. Meat Science, Kidlington, v. 56, n. 3, p. 291-299, 2000.

FALLEIROS, F. T.; MIGUEL, W. C.; GAMEIRO, A. H. A desinformação como obstáculo ao consumo da carne suína in natura. In: CONGRESSO DA SOCIEDADE BRASILEIRA DE ECONOMIA, ADMINISTRAÇÃO E SOCIOLOGIA RURAL, 46., 2008, Rio Branco. Anais... Rio Branco: SOBER, 2008. p. 1-13.

HACK, E. C. Geração de resíduos provenientes da suinocultura na região Oeste do Paraná: um caso de insustentabilidade. Scientia Agraria Paranaenis, Marechal Cândido Rondon, v. 10, n. 2, p. 21-36, 2011.

HAMM, R. Biochemistry of meat hydratation. Advances in Food Research, Cleveland, v. 10, n. 2, p. 335-443, 1960.

HANSEN, E.; JUNCHER, D.; HENCKEL, P.; KARLSSON, A.; BERTELSEN, G.; SKIBSTED, L. H. Oxidative stability of chilled pork chops following long term freeze storage. Meat Science, Kidlington, v. 68, n. 3, p. 479-484, 2004.

HORTA, F. C.; ECKHARDT, O. H. O.; GAMEIRO, A. H.; MORETTI, A. S. Estratégias de sinalização da qualidade da carne suína ao consumidor final. Revista Brasileira Agrociência, Pelotas, v. 16, n. 1-4, p. 15-21, 2010. 
JUNCHER, D.; RONN, B.; MORTENSEN, E. T.; HENCKEL, P.; KARLSSON, A.; KIBSTED, L. H.; BERTELSEN, G. Effect of pre-slaughter physiological conditions on the oxidative stability of colour and lipid during chill storage of pork. Meat Science, Kidlington, v. 58, n. 4, p. 347-357, 2001.

MAGANHINI, M. B.; MARIANO, B.; SOARES, A. L.; GUARNIERI, P. D.; SHIMOKOMAKI, M.; IDA, E. I. Carnes PSE (Pale, Soft, Exudative) e DFD (Dark, Firm, Dry) em lombo suíno numa linha de abate industrial. Ciência e Tecnologia de Alimentos, Campinas, v. 27, p. 69-72, 2007. Suplemento 1.

NGAPO, T. M. Consumer preferences for pork chops in five Canadian provinces. Meat Science, Barking, v. 129, p. 102-110, 2017.

ODA, S. H. I.; SCHNEIDER, J.; SOARES, A. L.; BARBOSA, D. M. L.; IDA, E. I.; OLIVO, R. SCHIMOKOMAKI, M. Detecção de cor em filés de peito de frango. Revista Nacional da Carne, São Paulo, v. 28, n. 321, p. 30-34, 2003.

SANTOS, T. M. B.; CAPPI, N.; SIMÕES, A. R. P.; SANTOS, V. A. C.; PAIANO, D.; GARCIA, E. R. M. Diagnóstico do perfil do consumidor de carne suína no município de Aquidauana-MS. Revista Brasileira Saúde Produção Animal, Salvador, v. 12, n. 1, p. 1-13, 2011.

SILVA, J. P.; SILVA, L. P. G. Estudo e avaliação do consumidor de carne suína in natura e industrializada na microrregião de Guarabira-PR. ACSA - Agropecuária Científica no Semiárido, Patos, v. 5, n. 1, p. 57-61, 2009.
SOARES, A. L.; LARA, J. A. F.; IDA, E. I.; GUARNIERI, P. D.; OLIVO, R.; SHIMOKOMAKI, M. Variation in the colour of brazilian broiler breast fillet. In: INTERNATIONAL CONGRESS OF MEAT SCIENCE AND TECHNOLOGY, 48., 2002, Roma. Proceedings... Roma: ICoMST, 2002. p. 540-541.

SOUZA, F. B. R.; FRANÇA, A. Z.; SILVEIRA, C. R.; ZOTTI, C. M.; XAVIER, E. G. Perfil do consumidor de carne suína no Município de PelotasRS. In: CONGRESSO DE INICIAÇÃO CIENTÍFICA, ENCONTRO DE PÓS-GRADUAÇÃO, MOSTRA CIENTIFICA, 17.; 11.; 1., 2007, Pelotas. Anais... Pelotas: FAEM, Universidade Federal de Pelotas, 2007. p. 1-15.

THOMS, E.; ROSSA, L. S.; STAHLKE, E. V. R.; FERRO, I. D.; MACEDO, R. E. F. Perfil de consumo e percepção da qualidade da carne suína por estudantes de nível médio da cidade de Irati, PR. Revista Acadêmica: Ciências Agrárias e Ambientais, Curitiba, v. 8, n. 4, p. 449-459, 2010.

ZAMBERLAN, L. A influência do atributo de segurança na segmentação dos consumidores de carne suína da região Fronteira Noroeste do Rio Grande do Sul. Santa Rosa - RS. 2002. Dissertação (Mestrado Executivo) - Escola Brasileira de Administração Pública e de Empresas, Fundação Getúlio Vargas, Santa Rosa. Disponível em: <http://bibliotecadigital.fgv.br/dspace/ handle/10438/3709>. Acesso em: 25 abr. 2017. 